\title{
Syntheses, Structures and Properties of 3d-4f Heterometallic Coordination Polymers Based on Tetradentate Metalloligand and Lanthanoid Ions
}

\author{
Xingnan Guo', Jun Qian'1*, Qiang Zhou' ${ }^{1}$, Chi Zhang2* \\ ${ }^{1}$ School of Chemistry and Chemical Engineering, Jiangsu University, Zhenjiang, China \\ ${ }^{2}$ China-Australia Joint Research Center for Functional Molecular Materials, Jiangsu University, Zhenjiang, China \\ Email: ^junqian8203@ujs.edu.cn, *chizhang@ujs.edu.cn
}

How to cite this paper: Guo, X.N., Qian, J., Zhou, Q. and Zhang, C. (2018) Syntheses, Structures and Properties of $3 \mathrm{~d}-4 \mathrm{f} \mathrm{He}-$ terometallic Coordination Polymers Based on Tetradentate Metalloligand and Lanthanoid Ions. Journal of Materials Science and Chemical Engineering, 6, 163-179. https://doi.org/10.4236/msce.2018.64016

Received: March 9, 2018

Accepted: April 27, 2018

Published: April 30, 2018

Copyright $\odot 2018$ by authors and Scientific Research Publishing Inc. This work is licensed under the Creative Commons Attribution International License (CC BY 4.0).

http://creativecommons.org/licenses/by/4.0/

(c) (i) Open Access

\begin{abstract}
Based on tetradentate metalloligand $\mathrm{L}^{\mathrm{Cu}}\left(\left[\mathrm{Cu}(2,4-\text { pydca })_{2}\right], 2,4-\right.$ pydca $=$ pyridine-2,4-dicarboxylate) and lanthanides $\left(\mathrm{Sm}^{3+}, \mathrm{Dy}^{3+}\right)$, two

3d-4fheterometalliccoordination polymers, namely,

$\left\{\left[\mathrm{Sm}_{2}(\mathrm{DMSO})_{4}\left(\mathrm{CH}_{3} \mathrm{OH}\right)_{2}\right]\left[\mathrm{L}^{\mathrm{Cu}}\right]_{3} \cdot 7 \mathrm{DMSO} \cdot 2 \mathrm{CH}_{3} \mathrm{OH}\right\}_{\mathrm{n}} 1$ and

$\left\{\left[\mathrm{Dy}_{2}(\mathrm{DMSO})_{3}\left(\mathrm{CH}_{3} \mathrm{OH}\right)\right]\left[\mathrm{L}^{\mathrm{Cu}}(\mathrm{DMSO})\right] \cdot 4 \mathrm{DMSO} \cdot \mathrm{CH}_{3} \mathrm{OH}\right\}_{\mathrm{n}} 2(\mathrm{DMSO}=\mathrm{di}-$ methyl sulfoxide), have been synthesized and well characterized by elemental analysis, Fourier-transform infrared spectroscopy, thermogravimetric and single-crystal X-ray diffraction analysis. Single-crystal X-ray analysis reveals that both 1 and 2 crystallize in the triclinic crystal system with $P-1$ space group and possess the $3 \mathrm{D}$ framework structures, which are constructed from metalloligands $\mathrm{L}^{\mathrm{Cu}}$ connecting with $\left\{\mathrm{Sm}_{2}\right\}$ and $\left\{\mathrm{Dy}_{2}\right\}$ clusters, respectively. The 3D structure of 1 has a 6-connected single-nodal topology with the point symbol $\left\{4^{9} \times 6^{6}\right\}$, while 2 features a different framework with the point symbol of $\left\{4^{12} \times 6^{3}\right\}$. Thermogravimetric analysis exhibits that the skeleton of both 1 and 2 collapse after $350^{\circ} \mathrm{C}$. Magnetic properties of 1 and 2 have also been investigated.
\end{abstract}

\section{Keywords}

Coordination Polymers, $\left\{\mathrm{Sm}_{2}\right\} /\left\{\mathrm{Dy}_{2}\right\}$ Clusters, Metalloligand, Crystal Structure, Magnetic Property

\section{Introduction}

Nowadays, a great deal of attention has been dedicated to the wide family of 
coordination compounds due to their unique molecular structures and potential applications in the field of luminescence, magnetism, catalysis and biochemistry [1] [2] [3] [4]. Current interest in these materials mainly focuses on the coordination polymers (CPs) associated with mixed-metal ions [5]. Among various approaches to the construction of heterometallic CPs, the most efficient one is to employ metalloligands that can connect with other metal centers, such as transition metal [6] [7] [8] and lanthanide ions [9]-[16]. For example, molecular building units $\left[\mathrm{M}(\mathrm{CN})_{8}\right]^{3-/ 4-}(\mathrm{M}=\mathrm{W}, \mathrm{Mo}, \mathrm{Nb})$ and $\left[\mathrm{MS}_{4}\right]^{2-}(\mathrm{M}=\mathrm{W}, \mathrm{Mo})$ have been successfully applied in the fabrication of heterometallic CPs as metalloligands [17] [18] [19] [20]. Recently, an O-containing metalloligand $\left[\mathrm{Cu}(2,4-\text { pydca })_{2}\right] \quad\left(\mathrm{L}^{\mathrm{Cu}}\right.$, see Scheme 1$)$ based on pyridine-2,4-dicarboxylate (2,4-pydca) has been developed [21]. Several heterobimetallic coordination compounds have been reported from the reaction between metalloligand $\mathrm{L}^{\mathrm{Cu}}$ and transition metal $\left(\mathrm{Mn}^{\mathrm{II}}, \mathrm{Co}^{\mathrm{II}}, \mathrm{Ni}^{\mathrm{II}}\right)$ [22] [23] [24] [25] [26], alkaline-earth ions [27].

On the other hand, the molecular structures and properties of CPs are also highly influenced by several critical factors during the synthetic process, such as $\mathrm{pH}$ values, metal-ligand ratio, solvent polarity, auxiliary ligands and synthetic strategy. For example, although several 3d-4f heterobimetallic CPs containing $\mathrm{L}^{\mathrm{Cu}}$ structure have been reported [28]-[33], in which the $\mathrm{L}^{\mathrm{Cu}}$ come from the reactions between cupric oxide/cupric nitrate and pyridine-2,4-dicarboxylic acid via the hydro-thermal reaction. However, the direct application of metalloligand $\mathrm{L}^{\mathrm{Cu}}$ in the construction of $3 \mathrm{~d}-4 \mathrm{f}$ heterometallic CPs has not been reported yet. In addition, the coexistence of $3 \mathrm{~d}$ transition metal and $4 \mathrm{f}$ lanthanide ions in one molecule may lead to various structures and physical properties due to the rich coordination environments of lanthanide and transition metal ions, which will finally affect the spatial configurations and magnetic couplings [34] [35] [36]. Meanwhile, benefited from the large spin values, spin-ion anisotropy and large spin-orbit couplings of lanthanide ions, $3 \mathrm{~d}-4 \mathrm{f}$ heterometallic CPs may exhibit fascinating and complicated magnetic behaviors [37] [38] [39]. Therefore, metalloligand $\mathrm{L}^{\mathrm{Cu}}$ and lanthanide centers $\left(\mathrm{Sm}^{3+}\right.$ and $\left.\mathrm{Dy}^{3+}\right)$ will be introduced for the construction of $3 \mathrm{~d}-4 \mathrm{f}$ coordination polymers with magnetic properties through

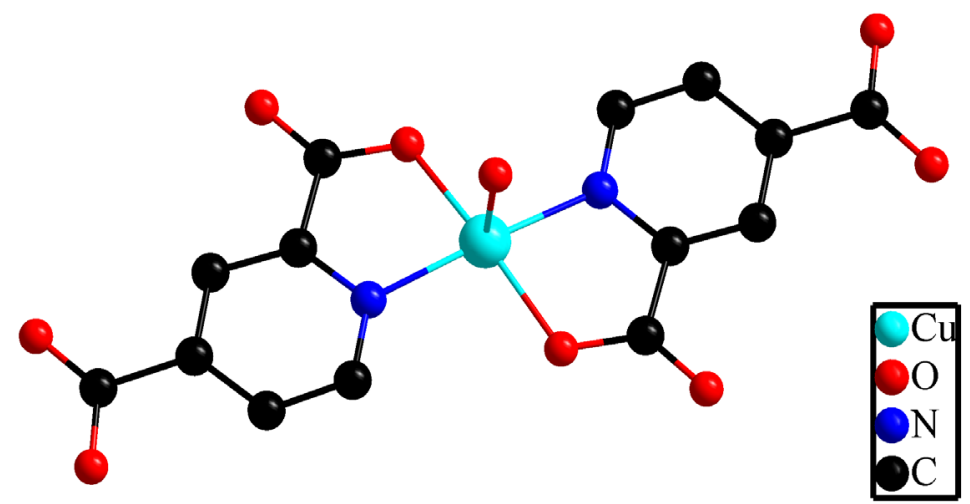

Scheme 1. Structure of $\mathrm{L}^{\mathrm{Cu}}$. Hydrogen atoms are omitted for clarity. 
the inter-diffusion method.

In this work, we have successfully synthesized two new $3 \mathrm{~d}-4 \mathrm{f}$ heterometallic CPs from the metalloligand $\mathrm{L}^{\mathrm{Cu}}$, i.e., $\left\{\left[\mathrm{Sm}_{2}(\mathrm{DMSO})_{4}\left(\mathrm{CH}_{3} \mathrm{OH}\right)_{2}\right]\left[\mathrm{L}^{\mathrm{Cu}}\right]_{3} \cdot 7 \mathrm{DMSO} \cdot 2 \mathrm{CH}_{3} \mathrm{OH}\right\}_{\mathrm{n}} 1$ and $\left\{\left[\mathrm{Dy}_{2}(\mathrm{DMSO})_{3}\left(\mathrm{CH}_{3} \mathrm{OH}\right)\right]\left[\mathrm{L}^{\mathrm{Cu} 3}(\mathrm{DMSO})\right] \cdot 4 \mathrm{DMSO} \cdot \mathrm{CH}_{3} \mathrm{OH}\right\}_{\mathrm{n}}$ 2. X-ray crystallographic studies reveals that both CPs 1 and 2 exhibit the 3D framework structures, which are constructed from metalloligands $\mathrm{L}^{\mathrm{Cu}}$ connecting with $\left\{\mathrm{Sm}_{2}\right\}$ and $\left\{\mathrm{Dy}_{2}\right\}$ clusters. 1 and 2 possess the different 6-connected single-nodal topology with point symbol $\left\{4^{9} \times 6^{6}\right\}$ and $\left\{4^{12} \times 6^{3}\right\}$, respectively. According to the molecular formula of CP-2, which has been determined definitively from the crystal structure, one of the metalloligand $\mathrm{L}^{\mathrm{Cu}}$ was changed into $\mathrm{L}^{\mathrm{Cu}}$ (DMSO) during the reaction process.Further, the TGA behaviors of two CPs have been measured in the temperature range of $25^{\circ} \mathrm{C}-800^{\circ} \mathrm{C}$, while the magnetic properties of 1 and 2 have also been investigated.

\section{Experimental Section}

\subsection{Materials and Physical Measurements}

All the chemicals and solvents were reagent grade and purchased from commercial sources and used without further purification. Pyridine-2,4-dicarboxylate acid and metalloligand $\mathrm{L}^{\mathrm{Cu}}$ were synthesized according to procedures already reported outlined in the literature [21]. Element analyses for $\mathrm{C}, \mathrm{H}$ and $\mathrm{N}$ were performed with a PerkineElmer $240 \mathrm{C}$ elemental analyzer. Infrared spectra were obtained from a sample powder pelletized with $\mathrm{KBr}$ disks on a Nicolet Nexus 470 spectrometer (Germany) over a range of $400-4000 \mathrm{~cm}^{-1}$. Thermogravimetric analysis (TGA) measurements were carried out in the temperature range of $25^{\circ} \mathrm{C}-800^{\circ} \mathrm{C}$ on a PerkineElmer Pyis 1 system in a nitrogenpurge with a heating rate of $10^{\circ} \mathrm{C} / \mathrm{min}$. The temperature dependence of molar magnetic susceptibility was measured under an applied field of $1000 \mathrm{G}$ in the form of $\chi_{\mathrm{m}} T$ versus $T$ in the range of 1.8 - $300 \mathrm{~K}$ by Quantum Design MPMS XL-5. The influence of sample holder background was subtracted by the automatic subtraction feature of the software.

\subsection{Preparation of $\left\{\left[\mathrm{Sm}_{2}(\mathrm{DMSO})_{4}\left(\mathrm{CH}_{3} \mathrm{OH}\right)_{2}\right]\left[\mathrm{LCu}_{3} \cdot 7 \mathrm{DMSO} \cdot 2 \mathrm{CH}_{3} \mathrm{OH}\right\}_{\mathrm{n}}\right.$ (1)}

The methanol solution of $\mathrm{Sm}\left(\mathrm{NO}_{3}\right)_{3} \cdot 6 \mathrm{H}_{2} \mathrm{O}(44 \mathrm{mg}, 0.1 \mathrm{mmol})$ was slowly diffused into a dimethyl sulfoxide solution (DMSO) of $\mathrm{L}^{\mathrm{Cu}}(62 \mathrm{mg}, 0.1 \mathrm{mmol})$ through $1 \mathrm{~mL}$ DMSO blank solvent as the buffer solution. After several days, the obtained blue crystals were collected by filtration, washed with methanol. Yield: $50 \mathrm{mg}, 60.6 \%$ (based on $\mathrm{Cu}$ ). Anal. Calcd for $\mathrm{C}_{68} \mathrm{H}_{88} \mathrm{Cu}_{3} \mathrm{~N}_{6} \mathrm{O}_{42} \mathrm{~S}_{11} \mathrm{Sm}_{2}(2453.57)$ : C, 33.29; H, 4.11; N, 3.41. Practical found: C, 33.32; H, 4.12; N, 3.40. IR $\left(\mathrm{KBr}, \mathrm{cm}^{-1}\right)$ : 3419(s), 2980(m), 2924(m), 2354(m), 1660(s), 1617(s), 1555(s), 1476(m), 1390(s), 1341(s), 1261(m), 1181(w), 1083(w), 1009(s), 942(m), 899(w), 825(w), 783(m), 739(m), 684(s), 530(w), 463(w). 


\subsection{Preparation of $\left\{\left[\mathrm{Dy}_{2}(\mathrm{DMSO})_{3}\left(\mathrm{CH}_{3} \mathrm{OH}\right)\right]\left[\mathrm{L}^{\mathrm{Cu}} 3(\mathrm{DMSO})\right] \cdot 4 \mathrm{DMSO} \cdot \mathrm{CH}_{3} \mathrm{OH}\right\}_{\mathrm{n}}$ (2)}

CP-2 was obtained as light blue block crystals with the same synthetic method as that of 1 except that $\mathrm{Sm}\left(\mathrm{NO}_{3}\right)_{3} \cdot 6 \mathrm{H}_{2} \mathrm{O}$ was replaced by $\mathrm{Dy}\left(\mathrm{NO}_{3}\right)_{3} \cdot 6 \mathrm{H}_{2} \mathrm{O}(46$ $\mathrm{mg}, \quad 0.1 \mathrm{mmol}$ ). Yield: $6 \mathrm{mg}, 18 \%$ (base on $\mathrm{Cu}$ ). Anal. Calcd for $\mathrm{C}_{60} \mathrm{H}_{60} \mathrm{Cu}_{3} \mathrm{~N}_{6} \mathrm{O}_{36} \mathrm{~S}_{8} \mathrm{Dy}_{2}(2195.38)$ : C, 32.83; H, 3.37; N, 3.83. Found: C, 32.56; $\mathrm{H}$, 3.36; N, 3.88. IR $\left(\mathrm{KBr}, \mathrm{cm}^{-1}\right)$ : 3434(s), 2992(w), 2912(w), 2372(s), 1654(s), 1611(s), 1537(m), 1476(w), 1402(s), 1329(s), 1248(w), 1089(w), 1022(m), 954(w), 832(w), 783(w), 733(m), 684(m), 524(w).

\subsection{Single-Crystal Structure Determination}

Sizeable and high-quality single crystals of two compounds were selected carefully from little glass tubes, and mounted on a glass fiber with epoxy resin covered. All measurements were obtained by a Rigaku Saturn $724^{+}$CCD imaging plate diffractometer with graphite-monochromated Mo-Ka radiation $(\lambda=$ $0.71073 \AA$ ) at room temperature. The two crystals structures were solved by direct methods, while the non-hydrogen atoms were subjected to anisotropic refinement on $\mathrm{F}^{2}$ through full-matrix least-squares with SHELX-97 package [40] [41] [42]. All the non-hydrogen atoms were determined with anisotropic thermal displacement coefficients. Hydrogen atoms were treated isotropically according to a riding model, beyond that the hydrogen atoms were located in idealized positions. The contribution of missing solvent molecules (DMSO, $\mathrm{CH}_{3} \mathrm{OH}$ ) to the diffraction pattern was subtracted from the reflection data by the "SQUEEZE" method as implemented in PLATON [43]. Details of the crystal parameters, data collection and refinement of CPs 1 and 2 are listed in Table 1, while the selected bond lengths are listed in Table 2.

\section{Results and Discussion}

\subsection{Synthetic Method}

CPs 1 and 2 were crystallized from the reactions between metalloligand $\left[\mathrm{Cu}(2,4 \text {-pydca })_{2}\right]$ and $\mathrm{Sm}\left(\mathrm{NO}_{3}\right)_{3} \cdot 6 \mathrm{H}_{2} \mathrm{O} / \mathrm{Dy}\left(\mathrm{NO}_{3}\right)_{3} \cdot 6 \mathrm{H}_{2} \mathrm{O}$, respectively. According to the literature, the reported pydca-based $3 \mathrm{~d}-4 \mathrm{f}$ structures were obtained from rare earth hydrates, copper oxide/copper acetate hydrate and pyridine-2,4-dicarboxylic acid through the hydro-thermal synthetic approach [28]-[33]. Compared to the hydro-thermal syntheses of above pydca-based $3 \mathrm{~d}-4 \mathrm{f}$ structures, the inter-diffusion method was applied as a mild way for the crystallization of 1 and 2. In this work, our synthetic strategy uses DMSO as the buffer solution, which can slow the interactions between $\mathrm{L}^{\mathrm{Cu}}$ and lanthanide ions. As a result, well shaped crystals of 1 and 2 can be obtained from the cushion breaker. It is obviously that the use of blank solvent as buffer solution provides a stable condition for the reaction between two different reactive components [21]. Compared with the conventional hydro-thermal/solvent-thermal synthetic 
Table 1. Crystal data for 1 and 2 .

\begin{tabular}{|c|c|c|}
\hline Compound & 1 & 2 \\
\hline Empirical formula & $\mathrm{C}_{68} \mathrm{H}_{88} \mathrm{Cu}_{3} \mathrm{~N}_{6} \mathrm{O}_{42} \mathrm{~S}_{11} \mathrm{Sm}_{2}$ & $\mathrm{C}_{60} \mathrm{H}_{60} \mathrm{Cu}_{3} \mathrm{~N}_{6} \mathrm{O}_{36} \mathrm{~S}_{8} \mathrm{Dy}_{2}$ \\
\hline Formula weight & 2453.57 & 2195.38 \\
\hline Crystal system & Triclinic & Triclinic \\
\hline Space group & $\mathrm{P}-1$ & $\mathrm{P}-1$ \\
\hline $\mathrm{a} / \AA$ & $11.9943(5)$ & $17.005(3)$ \\
\hline $\mathrm{b} / \AA$ & $13.3535(5)$ & $17.539(3)$ \\
\hline$c / \AA$ & $15.4288(6)$ & $21.668(4)$ \\
\hline$\alpha l^{\circ}$ & $110.795(2)$ & $92.01(3)$ \\
\hline$\beta 1^{\circ}$ & $101.239(2)$ & $104.49(3)$ \\
\hline$\gamma /{ }^{\circ}$ & $94.795(2)$ & $107.16(3)$ \\
\hline Volume $/ \AA^{3}$ & $2234.21(15)$ & $5936.8(18)$ \\
\hline $\mathrm{Z}$ & 1 & 2 \\
\hline Absorption coefficient & 2.157 & 1.913 \\
\hline $\mathrm{F}(000)$ & 911 & 1914 \\
\hline $\mathrm{R}_{\text {int }}$ & 0.0328 & 0.0434 \\
\hline Completeness & $99.4 \%$ & $96.5 \%$ \\
\hline GooF & 1.055 & 1.054 \\
\hline \multirow{2}{*}{$\mathrm{R}(\mathrm{I}>2 \sigma(\mathrm{I}))$} & $\mathrm{R} 1=0.0584$ & $\mathrm{R} 1=0.0494$ \\
\hline & $\mathrm{wR} 2=0.1555$ & $\mathrm{wR} 2=0.1327$ \\
\hline \multirow{2}{*}{$\mathrm{R}$ (all data) } & $\mathrm{R} 1=0.0642$ & $\mathrm{R} 1=0.0558$ \\
\hline & $\mathrm{wR} 2=0.1600$ & $\mathrm{wR} 2=0.1369$ \\
\hline Largest diff peak and hole & $3.612,-3.757$ & $1.697,-1.770$ \\
\hline
\end{tabular}

approach, the inter-diffusion method here plays an important role in the crystallization process of CPs 1 and 2 .

\subsection{Crystal Structure of 1}

The result of single crystal X-ray structural analysis reveals that CP-1 crystallizes in the triclinic crystal system with $P-1$ space group and exhibits a 3D framework structure. The asymmetric unit consists of one $\left[\mathrm{Sm}(\mathrm{DMSO})_{2}\left(\mathrm{CH}_{3} \mathrm{OH}\right)\right]^{3+}$ cation, one and half $\left[\mathrm{L}^{\mathrm{Cu}}\right]^{2-}$ ions.

The coordination mode of $\mathrm{Sm}$ atom and the connecting modes of $\mathrm{L}^{\mathrm{Cu}}$ metalloligands in CP-1 are shown in Figure 1. As in Figure 1(a), each Sm atom is coordinated by eight $\mathrm{O}$ atoms from five $\mathrm{L}^{\mathrm{Cu}}$ metalloligands, two DMSO molecules and one $\mathrm{CH}_{3} \mathrm{OH}$ molecule forming a square antiprism spatial configuration and exhibiting $D_{4 \mathrm{~d}}$ symmetry. In accordance with Figures 1(b)-(d), CP-1 have three different $\mathrm{L}^{\mathrm{Cu}}$ metalloligands: both $\mathrm{L}^{\mathrm{Cul}}$ and $\mathrm{L}^{\mathrm{Cu} 5}$ units connect with four Sm atoms through the carboxylic oxygen atoms showing a four-connecting mode, while the $\mathrm{L}^{\mathrm{Cu} 4}$ unit connect with two Sm atoms exhibiting a single-bridged mode. Attributable to the bidentate coordination mode of carboxylic acid in $\mathrm{L}^{\mathrm{Cul}}$ and 
Table 2. Selected bond lengths $(\AA)$ for 1 and 2 .

\begin{tabular}{|c|c|c|c|}
\hline \multicolumn{4}{|c|}{1} \\
\hline $\mathrm{Sm}(1)-\mathrm{O}(11)$ & $2.315(4)$ & $\mathrm{Cu}(1)-\mathrm{N}(3) \# 1$ & $1.959(5)$ \\
\hline $\mathrm{Sm}(1)-\mathrm{O}(5)$ & $2.349(4)$ & $\mathrm{Cu}(1)-\mathrm{N}(3)$ & $1.959(5)$ \\
\hline $\operatorname{Sm}(1)-O(6)$ & $2.361(4)$ & $\mathrm{Cu}(4)-\mathrm{O}(14)$ & $1.935(5)$ \\
\hline $\mathrm{Sm}(1)-\mathrm{O}(8)$ & $2.372(5)$ & $\mathrm{Cu}(4)-\mathrm{O}(14) \# 2$ & $1.935(5)$ \\
\hline $\mathrm{Sm}(1)-\mathrm{O}(4)$ & $2.397(4)$ & $\mathrm{Cu}(4)-\mathrm{N}(2) \# 2$ & $1.945(6)$ \\
\hline $\operatorname{Sm}(1)-O(3)$ & $2.435(4)$ & $\mathrm{Cu}(4)-\mathrm{N}(2)$ & $1.945(6)$ \\
\hline $\mathrm{Sm}(1)-\mathrm{O}(9)$ & $2.445(5)$ & $\mathrm{Cu}(5)-\mathrm{O}(2) \# 3$ & $1.925(5)$ \\
\hline $\mathrm{Cu}(1)-\mathrm{O}(13)$ & $1.940(6)$ & $\mathrm{Cu}(5)-\mathrm{N}(1) \# 3$ & $1.953(5)$ \\
\hline $\mathrm{Cu}(1)-\mathrm{O}(13) \# 1$ & $1.940(6)$ & $C(7)-O(6) \# 4$ & $1.244(7)$ \\
\hline $\mathrm{O}(6)-\mathrm{C}(7) \# 4$ & $1.244(7)$ & $\operatorname{Sm}(1) \ldots \operatorname{Sm}(1) \# 2$ & $4.491(1)$ \\
\hline \multicolumn{4}{|c|}{2} \\
\hline $\operatorname{Dy}(1)-O(21) \# 1$ & $2.260(3)$ & $\mathrm{Cu}(1)-\mathrm{N}(6)$ & $1.962(4)$ \\
\hline $\operatorname{Dy}(1)-O(27)$ & $2.334(3)$ & $\mathrm{Cu}(1)-\mathrm{N}(5)$ & $1.963(4)$ \\
\hline Dy(1)-O(11) & $2.452(3)$ & $\mathrm{Cu}(2)-\mathrm{O}(6) \# 2$ & $1.950(5)$ \\
\hline $\operatorname{Dy}(1)-O(12)$ & $2.460(3)$ & $\mathrm{Cu}(2)-\mathrm{N}(2) \# 2$ & $1.960(5)$ \\
\hline Dy(2)-O(53) & $2.281(5)$ & $\mathrm{Cu}(2)-\mathrm{O}(51)$ & $2.238(9)$ \\
\hline Dy(2)-O(16) & $2.285(3)$ & $\mathrm{Cu}(3)-\mathrm{N}(3) \# 3$ & $1.956(5)$ \\
\hline Dy(2)-O(14) & $2.326(3)$ & $\mathrm{Cu}(3)-\mathrm{O}(4) \# 3$ & $1.965(4)$ \\
\hline Dy(2)-O(7) & $2.360(3)$ & $\mathrm{O}(4)-\mathrm{Cu}(3) \# 4$ & $1.965(4)$ \\
\hline $\operatorname{Dy}(2)-O(22) \# 1$ & $2.365(3)$ & $\mathrm{O}(21)-\mathrm{Dy}(1) \# 6$ & $2.260(3)$ \\
\hline $\mathrm{O}(6)-\mathrm{Cu}(2) \# 5$ & $1.950(5)$ & $\operatorname{Dy}(1) \ldots \operatorname{Dy}(2)$ & $5.020(1)$ \\
\hline
\end{tabular}

Symmetry transformations used to generate equivalent atoms for 1 : \#1 $-\mathrm{x},-\mathrm{y},-\mathrm{z}-1 ; \# 2-\mathrm{x}+2,-\mathrm{y}+1,-\mathrm{z}$ $+1 ; \# 3-\mathrm{x}+2,-\mathrm{y}+1,-\mathrm{z} ; \# 4-\mathrm{x}+1,-\mathrm{y},-\mathrm{z}$; for 2 : \#1 x $-1, \mathrm{y}, \mathrm{z} ; \# 2 \mathrm{x}, \mathrm{y}-1, \mathrm{z} ; \# 3 \mathrm{x}, \mathrm{y}, \mathrm{z}-1$; \#4 x, y, z + 1; \#5 $\mathrm{x}, \mathrm{y}+1, \mathrm{z} ; \# 6 \mathrm{x}+1, \mathrm{y}, \mathrm{z}$.

$\mathrm{L}^{\mathrm{Cu} 5}$ units, a $\left\{\mathrm{Sm}_{2}\right\}$ cluster is constituted by four $\mu_{2}$-bridged carboxyl groups (Figure 2(a)). These $\left\{\mathrm{Sm}_{2}\right\}$ clusters can be linked by four $\mathrm{L}^{\mathrm{Cu}}$ metalloligands to build a quadrangular ring (Figure 2(b)). Extension of such rings through six-connected $\left\{\mathrm{Sm}_{2}\right\}$ clusters leads to the whole 2D layer structure (Figure 2(c)) showing a classic sql network (Figure 2(d)). These 2D layers are further extended to the 3D framework (Figure 2(e)) via the $\mathrm{L}^{\mathrm{Cu} 4}$ metalloligands (Figure $2(\mathrm{f})$ ), which can be regarded as the pillars of the $3 \mathrm{D}$ structure. The packing diagram showing the $3 \mathrm{D}$ extending structure of CP-1 from a axis is displayed in Figure 3. As in Figure 3, CP-1 exhibits a porous structure with various channels traversing the framework. Due to the small steric hindrance of DMSO molecules and long lengths of $\mathrm{L}^{\mathrm{Cu}}$ units, 3D framework of 1 possesses big cavities in these channels. The solvent accessible volume of CP-1 calculated by PLATON is 855.1 $\AA^{3}$ (38.3\%), which is large enough for hosting the solvent molecules (seven DMSO and two $\mathrm{CH}_{3} \mathrm{OH}$ ). The network analysis based on TOPOS program reveals that CP-1 can be simplified to a $(6,6)$-connected network with $\left\{4^{9} \times 6^{6}\right\}$ topology, which is depicted in Figure 4. As in Figure 4, the $\left\{\mathrm{Sm}_{2}\right\}$ clusters act as 

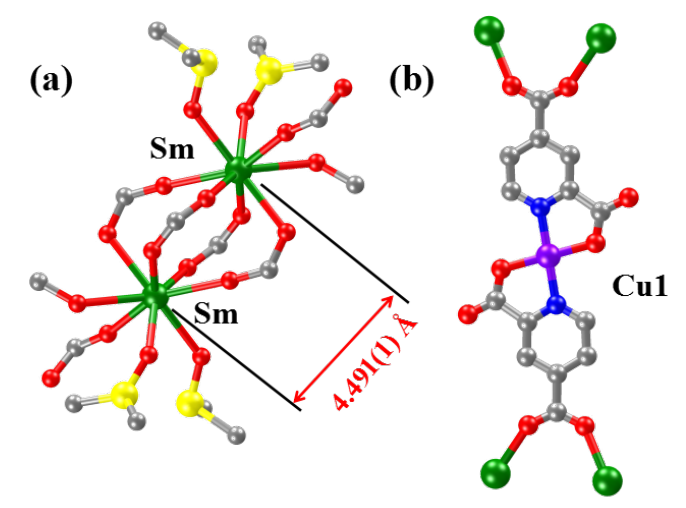

(c)

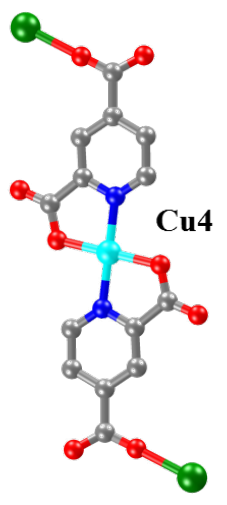

(d)

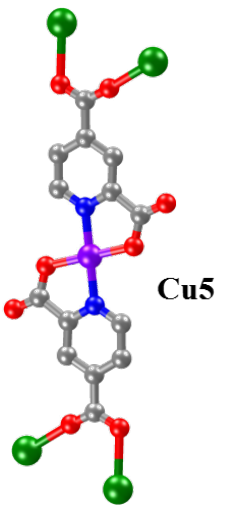

Figure 1. (a) Coordination mode of Sm atom; (b) Connecting mode of $\mathrm{L}^{\mathrm{Cu}}$ unit (Cu1) in CP-1; (c) Connecting mode of $\mathrm{L}^{\mathrm{Cu}}$ unit (Cu4) in CP-1; (d) Connecting mode of $\mathrm{L}^{\mathrm{Cu}}$ unit (Cu5) in CP-1. Hydrogen atoms and coordinated $\mathrm{O}$ atom are omitted for clarity.

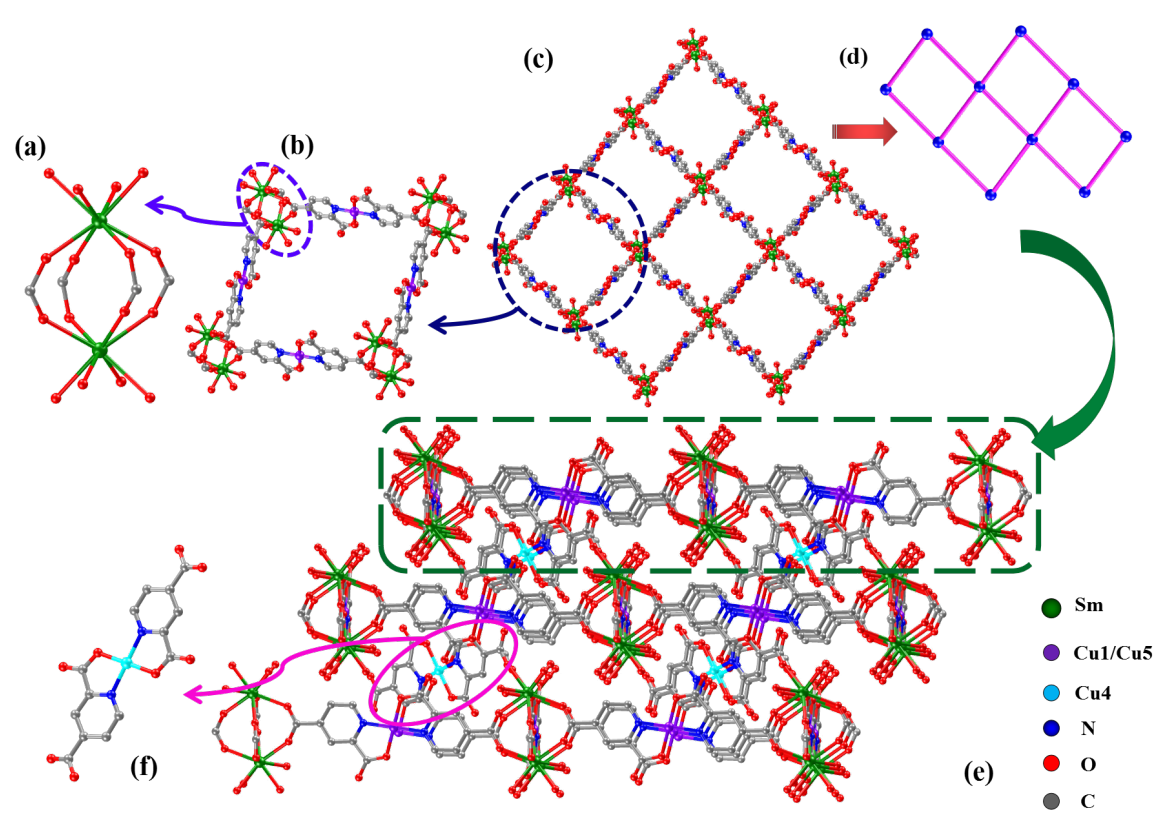

Figure 2. (a) $\left\{\mathrm{Sm}_{2}\right\}$ cluster; (b) Quadrangular ring from four $\left\{\mathrm{Sm}_{2}\right\}$ clusters and four $\mathrm{L}^{\mathrm{Cu}}$ units; (c) 2D network structure in CP-1; (d) sqltopologystructure; (e) 3D framework of CP-1; (f) $\mathrm{L}^{\mathrm{Cu}}$ unitin CP-1 $\left(\mathrm{Cu}^{4}\right)$. Hdrogen atoms are omitted for clarity. 


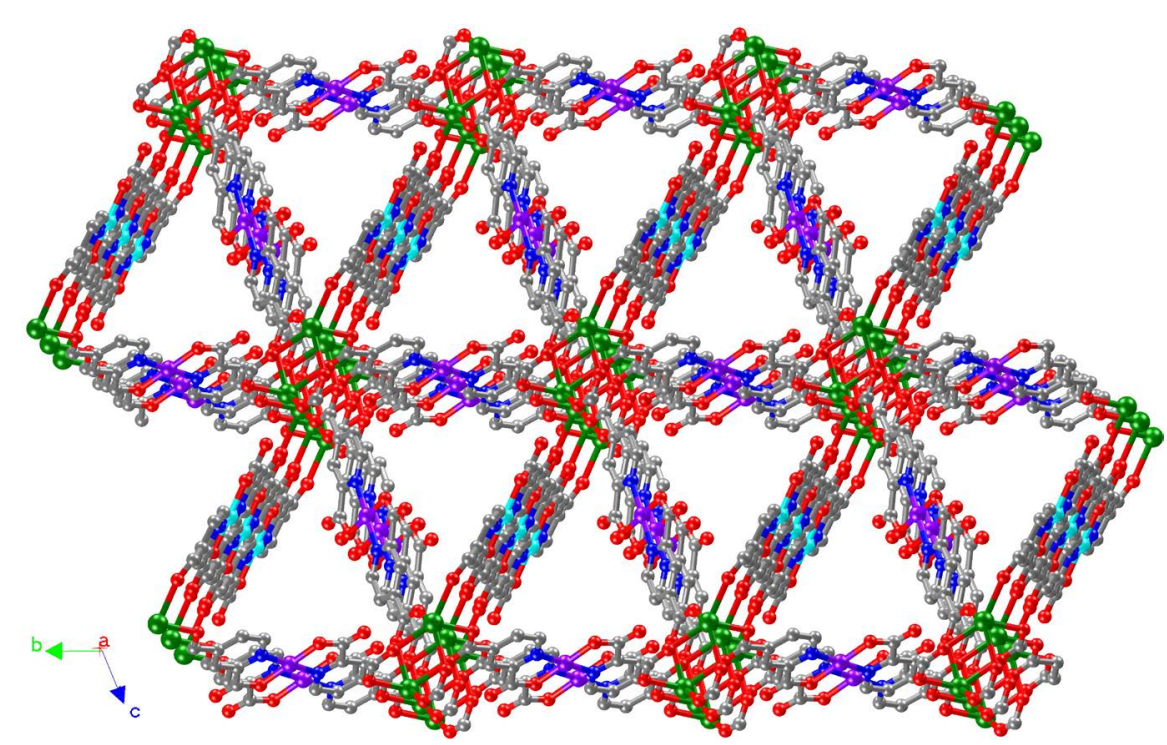

Figure 3. Packing structure of CP-1 (a axis). Hydrogen atoms and DMSO molecules are omitted for clarity.

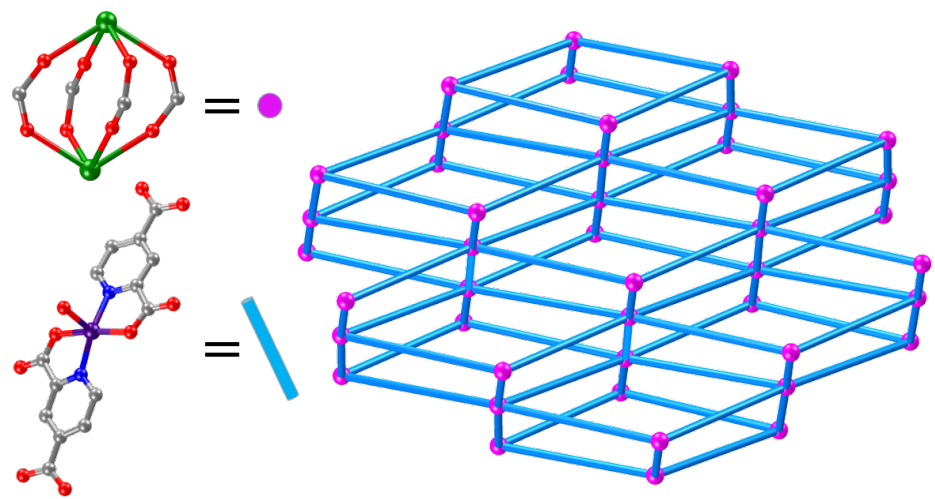

Figure 4. Topological structure of CP-1.

the vertexes of the geometry, while the sides are formed by $\mathrm{L}^{\mathrm{Cu}}$ metalloligands.

The selected bond lengths of CPs 1 and 2 are listed in Table 2. As shown in Table 2, the lengths of $\mathrm{Cu}-\mathrm{N}$ bond range from 1.981(3) to 1.984(3) $\AA$, while the value of $\mathrm{Cu}-\mathrm{O}$ fall into the range of 1.971(3)-2.238(4) $\AA$. Among the $\mathrm{Cu}-\mathrm{O}$ bond, the lengths between $\mathrm{Cu}$ atoms and $\mathrm{O}$ atoms from water molecules are larger than the distances between $\mathrm{Cu}$ atoms and $\mathrm{O}$ atoms from carboxylates. Bond lengths of Sm-O vary from $2.316(4)$ to $2.531(8) \AA$. In the $\left\{\mathrm{Sm}_{2}\right\}$ cluster, the shortest distance between two Sm atoms is 4.491(1) ̊.

\subsection{Crystal Structure of 2}

The X-ray crystallography study identifies that CP-2 also crystallizes in the triclinic crystal system with $P-1$ space group and consists of the porous 3D framework structure. The asymmetric unit of CP-2 contains one $\left[\mathrm{Dy}(\mathrm{DMSO})_{2}\right]^{3+}$ cation, one $\left[\mathrm{Dy}(\mathrm{DMSO})\left(\mathrm{CH}_{3} \mathrm{OH}\right)\right]^{3+}$ cation, two $\left[\mathrm{L}^{\mathrm{Cu}}\right]^{2-}$ ions and one $\left[\mathrm{L}^{\mathrm{Cu}}(\mathrm{DMSO})\right]^{2-}$ ion. Interestingly, one of the terminal coordinated $\mathrm{O}$ atom from $\mathrm{L}^{\mathrm{Cu}}$ has been re- 
placed by a DMSO molecule during the synthetic process of CP-2.

In accordance with Figure 5(a), Dy atoms in CP-2 have two different coordination environments: Dy1 is coordinated by eight $\mathrm{O}$ atoms from four $\mathrm{L}^{\mathrm{Cu}}$ metalloligands, one $\mathrm{L}^{\mathrm{Cu}}$ (DMSO) metalloligand and two DMSO molecules, while Dy2 is coordinated by eight $\mathrm{O}$ atoms from four $\mathrm{L}^{\mathrm{Cu}}$ metalloligands, one $\mathrm{L}^{\mathrm{Cu}}$ (DMSO) metalloligand, one DMSO molecule and one $\mathrm{CH}_{3} \mathrm{OH}$ molecule. According to the concrete crystal structure, there are three kinds of $\mathrm{L}^{\mathrm{Cu}}$ metalloligands in CP-2. As shown in Figure 5(b) and Figure 5(c), both $\mathrm{L}^{\mathrm{Cu} 1}$ (DMSO) and $\mathrm{L}^{\mathrm{Cu} 2}$ units in a four-connected mode are linked with two Dy1 and two Dy2 atoms through the carboxylic oxygen atoms. The $\mathrm{L}^{\mathrm{Cu} 3}$ unit in CP-2 connects with one Dy1 and one

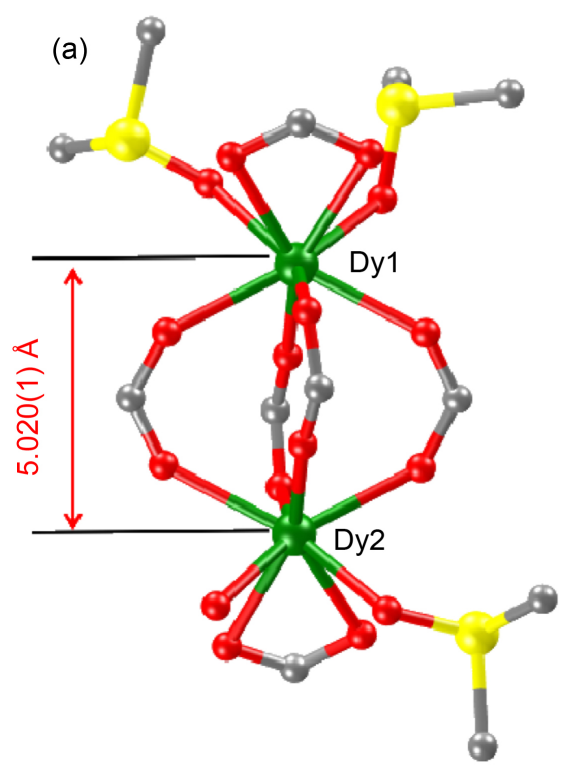

(b)

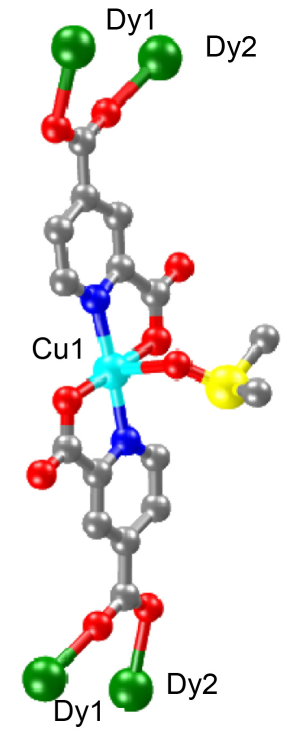

(c)

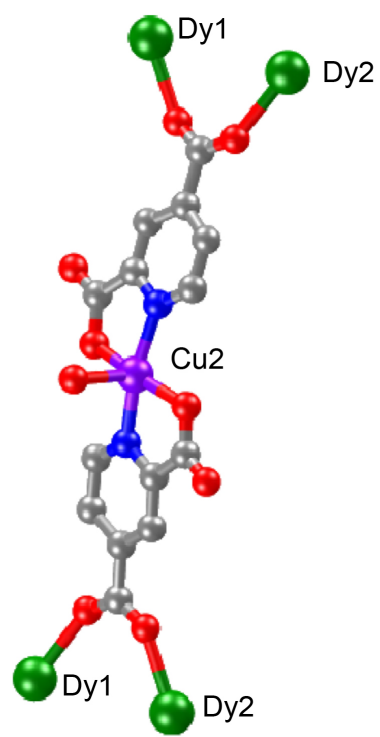

(d)

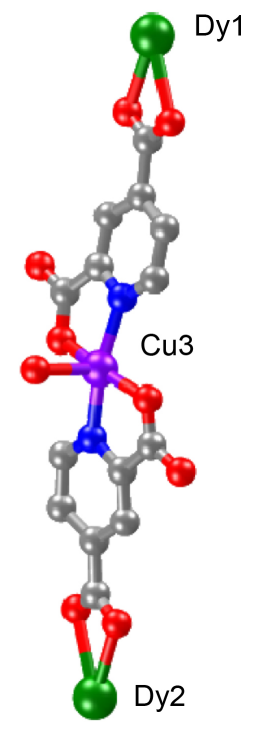

Figure 5. (a) Coordination modes of Dy1 and Dy2 atoms; (b) Connecting mode of $\mathrm{L}^{\mathrm{Cu}}$ unit (Cu1) in CP-2; (c) Connecting mode of $\mathrm{L}^{\mathrm{Cu}}$ unit (Cu2) in CP-2; (d) Connecting mode of $\mathrm{L}^{\mathrm{Cu}}$ unit (Cu3) in CP-2. Hydrogen atoms are omitted for clarity. 
Dy2 atom via four carboxylic oxygen atoms with the chelate mode (Figure 5(d)). Similarly to CP-1, Dy1 and Dy2 atom in CP-2 can be built to a $\left\{\mathrm{Dy}_{2}\right\}$ cluster with the help of $\mathrm{L}^{\mathrm{Cu} 1}$ (DMSO) and $\mathrm{L}^{\mathrm{Cu} 2}$ units (Figure 6(a)). The connection of such $\left\{\mathrm{Dy}_{2}\right\}$ clusters and $\mathrm{L}^{\mathrm{Cu}}$ metalloligands ( $\mathrm{Cu} 2$ and $\left.\mathrm{Cu} 3\right)$ through the carboxyl groups also forms a quadrangular configuration (Figure 6(b)). As depicted in Figure 6(c), these quadrangular configurations link with each other to construct the $2 \mathrm{D}$ network structure with $(4,4)$ topology. With the assist of $\mathrm{L}^{\mathrm{Cul}}$ (DMSO) (Figure 6(d)), these 2D networks can also be extended to a 3D framework structure (Figure 6(e)). The overall structure of CP-2 can be viewed as a grid-like frame with square channels traversing the framework (Figure 7). The solvent accessible volume of CP-2 is $2945.2 \AA^{3}$ (49.6\%), which is large enough for hosting the solvent molecules (four DMSO and one $\mathrm{CH}_{3} \mathrm{OH}$ ). The regular 6-connected mode of $\left\{\mathrm{Dy}_{2}\right\}$ cluster lead to a $\left\{4^{12} \times 6^{3}\right\}$ topological network (Figure 8). The topology structural difference between CP-1 and CP-2 is mainly due to the distinct connection modes of $\mathrm{L}^{\mathrm{Cu}}$ metalloligands in CPs 1 and 2 .

The averagelength (1.971(4) $\AA$ ) of $\mathrm{Cu}-\mathrm{N}$ bond in CP-2 is little larger than the value that in $\mathrm{CP}-1$ (1.952(5) $\AA$ ). As for the $\mathrm{Cu}-\mathrm{O}$ bond in $\mathrm{CP}-2$, the bond lengths range from $1.933(4) \AA$ to $2.388(5) \AA$. The distance $(2.388(5) \AA$ ) between $\mathrm{Cu}$

(a)

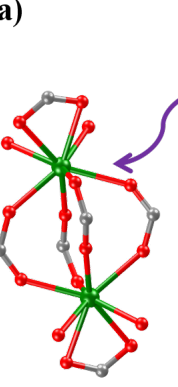

(b)

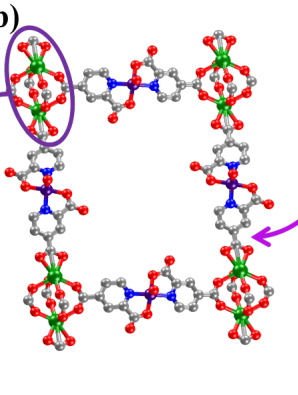

(c)

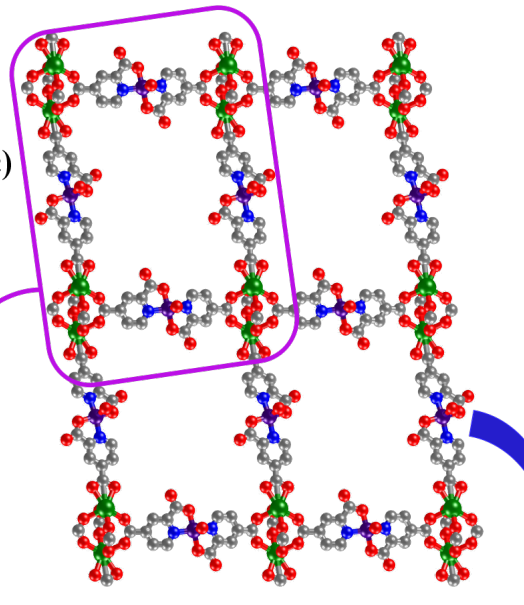

(d)

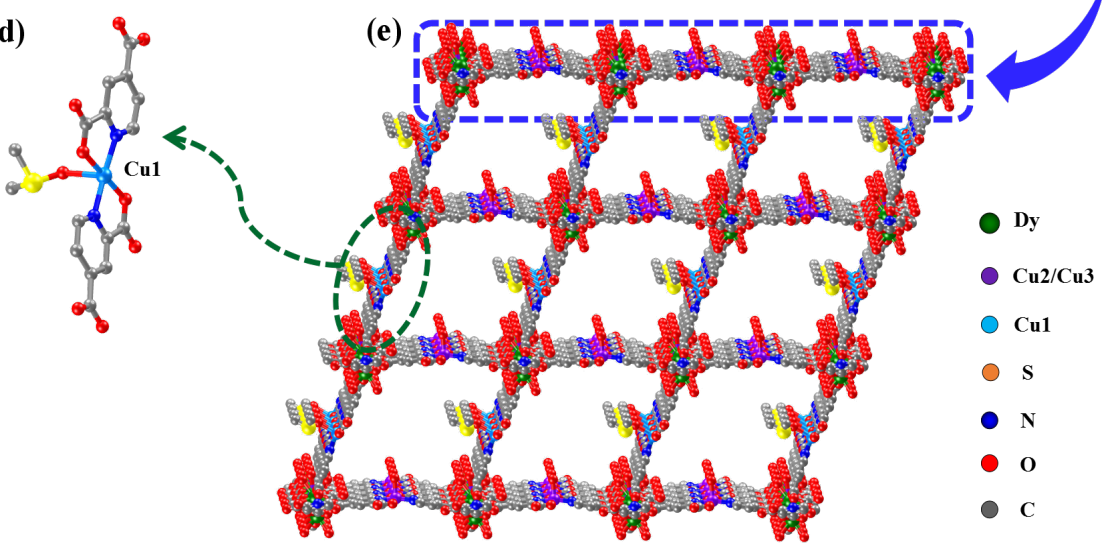

Figure 6. (a) $\left\{\mathrm{Dy}_{2}\right\}$ cluster; (b) Grid-likering from four $\left\{\mathrm{Dy}_{2}\right\}$ clusters and four $\mathrm{L}^{\mathrm{Cu}}$ units; (c) 2D network structure in CP-2; (d) $\mathrm{L}^{\mathrm{Cu}}$ unit in CP-2 (Cu1); (e) 3D framework of CP-2. Hydrogen atoms are omitted for clarity. 


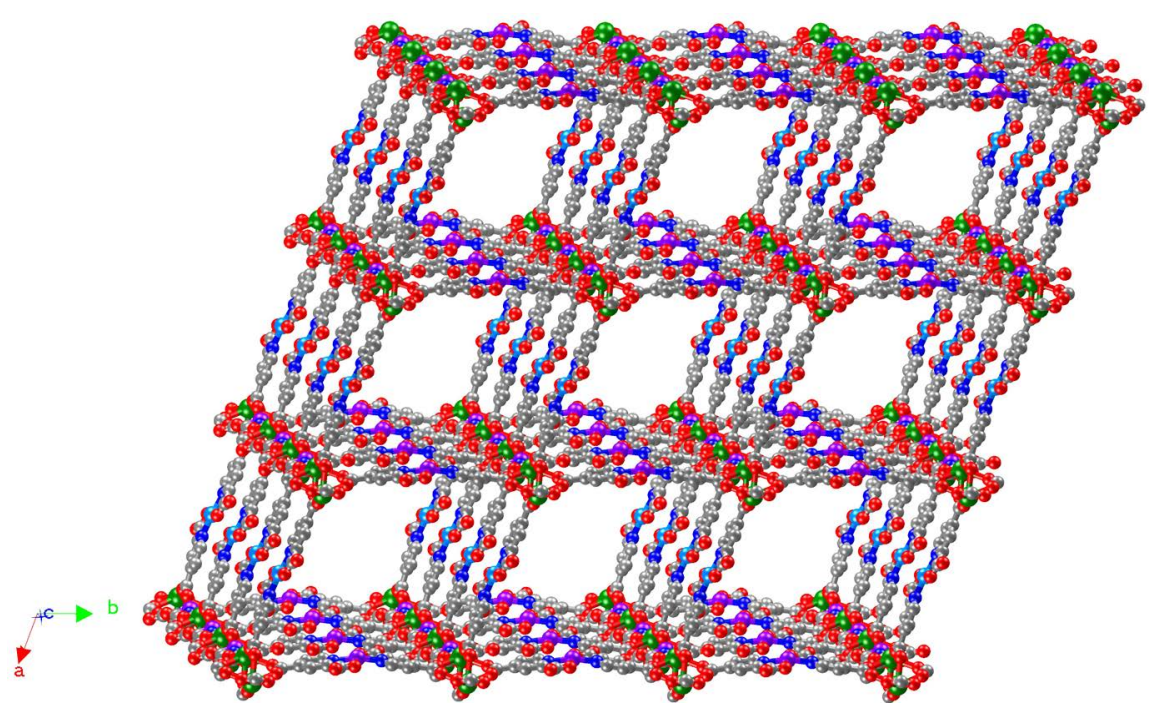

Figure 7. Packing structure of CP-2 ( $c$ axis). Hydrogen atoms and DMSO molecules are omitted for clarity.

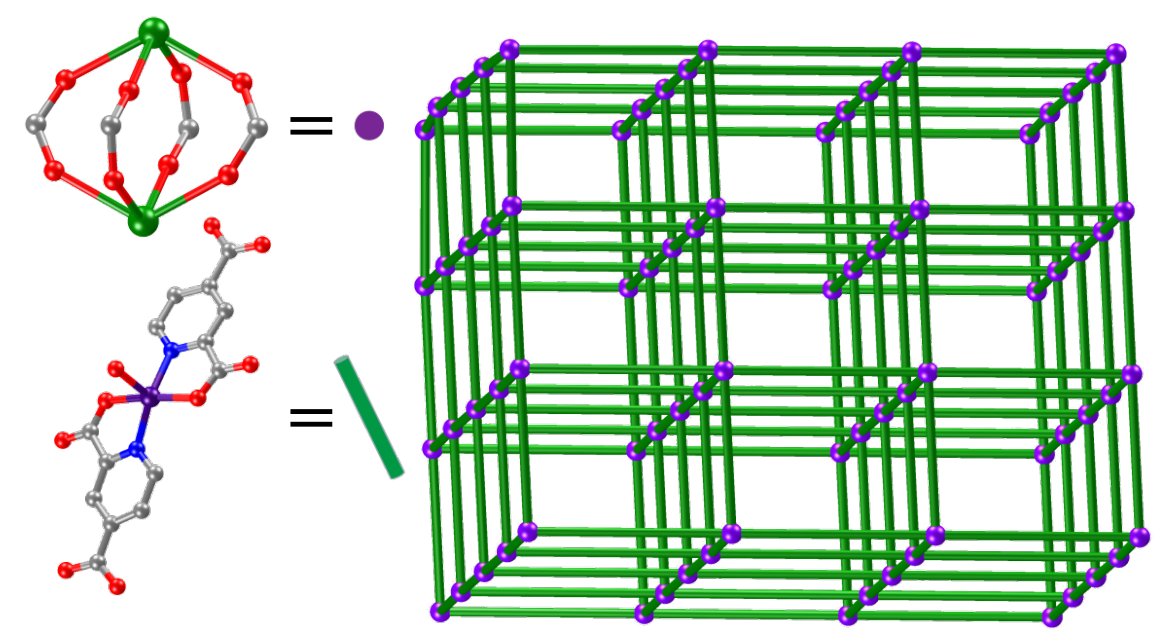

Figure 8. Topological structure of CP-2.

atom and $\mathrm{O}$ atom from DMSO molecule is little larger than the value between $\mathrm{Cu}$ atoms and $\mathrm{O}$ atoms from water molecules (2.238(9) $\AA$ for $\mathrm{Cu} 2,2.306(8) \AA$ for $\mathrm{Cu} 3)$. Bond lengths of Dy-O range from 2.260(3) $\AA$ to 2.808(5) $\AA$. The shortest distance of Dy $\cdots$ Dy in $\left\{\mathrm{Dy}_{2}\right\}$ cluster is 5.020(1) $\AA$ in the CP-2.

\subsection{Thermogravimetric Analysis}

Thermal properties of CPs 1 and 2 were examined by thermogravimetric analysis (TGA) from $25^{\circ} \mathrm{C}$ to $800^{\circ} \mathrm{C}$ in a nitrogen atmosphere with a heating rate of $10^{\circ} \mathrm{C} / \mathrm{min}$. Thethermogravimetric curve of CPs 1 and 2 are shown in Figure 9. As shown in the Figure 9, the first weight loss of $\mathrm{CP} 1$ (5.21\%) occurs from $50^{\circ} \mathrm{C}$ to $118^{\circ} \mathrm{C}$, corresponding to the loss of four methanol molecules (calcd: $5.22 \%$ ). Further weight loss (19.05\%) appears from $142^{\circ} \mathrm{C}$ to $236^{\circ} \mathrm{C}$, corresponding to the loss of six free DMSO molecules (calcd: $19.10 \%$ ). In the temperature range of 
$273^{\circ} \mathrm{C}-341^{\circ} \mathrm{C}$, four coordinated and one free DMSO molecules (15.84\%) lose with the rise of temperature (calcd: $15.92 \%$ ). After $350^{\circ} \mathrm{C}$, the organic groups of CP-1 start to lose and the skeleton structure starts to crumble. As for CP-2, the first weight loss of $2.86 \%$ (calcd: $2.92 \%$ ) is observed from $50^{\circ} \mathrm{C}$ to $110^{\circ} \mathrm{C}$ for two $\mathrm{MeOH}$ molecules, which is similar to that of $\mathrm{CP}-1$. The following weight loss (14.07\%) occurs from $158^{\circ} \mathrm{C}$ to $229^{\circ} \mathrm{C}$, which is corresponding to four solvent DMSO molecules (calcd: 14.23\%). The third stage of weight loss (14.96\%) starts at $280^{\circ} \mathrm{C}$, after that, four coordinated DMSO molecules escape until $342^{\circ} \mathrm{C}$ (calcd: $14.23 \%$ ). With the increase in temperature, the 3D framework of CP-2 begins to collapse.

\subsection{Magnetic Properties}

The temperature dependence of magnetic susceptibility is recorded for crystalline samples of CPs 1 and 2 at an applied magnetic field of 1000 Oe in the temperature range of $1.8-300 \mathrm{~K}$. The measurement results are shown in Figure 10 and Figure 11, respectively, in which $\chi_{\mathrm{m}}$ is the molar magnetic susceptibility. As in Figure 10, The $\chi_{\mathrm{m}} T$ values of CP-1 at room temperature is $1.62 \mathrm{~cm}^{3} \mathrm{~K} \mathrm{~mol}^{-1}$, which is a little smaller than the theoretical value $\left(1.69 \mathrm{~cm}^{3} \mathrm{~K} \mathrm{~mol}^{-1}\right)$ for a two isolated $\mathrm{Sm}^{3+}$ ions $(S=5 / 2, g=2 / 7)$ and three $\mathrm{Cu}^{2+}$ ions $(S=1 / 2, g=2)$ without magnetic interaction. Upon decreasing the temperature, the $\chi_{\mathrm{m}} T$ product drops slowly to a minimum of $0.47 \mathrm{~cm}^{3} \mathrm{~K} \mathrm{~mol}^{-1}$ at $1.8 \mathrm{~K}$. This decrease in $\chi_{\mathrm{m}} T$ may originate in the antiferromagnetic interaction between metal centers. The magnetic data in the range of $50-300 \mathrm{~K}$ followed the Curiee-Weiss fitting with a $\mathrm{Cu}$ rie constant of $C=1.8 \mathrm{~cm}^{3} \mathrm{~K} \mathrm{~mol}^{-1}$ and negative Weiss constant of $\theta=-57.7 \mathrm{~K}$. As shown in Figure 11, the room temperature $\chi_{\mathrm{m}} T$ value of CP-2 is $29.36 \mathrm{~cm}^{3} \mathrm{~K}$ $\mathrm{mol}^{-1}$, which is a little smaller than the theoretical value of $29.48 \mathrm{~cm}^{3} \mathrm{~K} \mathrm{~mol}^{-1}$ for three $\mathrm{Cu}^{2+}$ ion $(S=1 / 2, g=2)$ and two $\mathrm{Dy}^{3+}$ ions $(S=5 / 2, g=4 / 3)$ due to the thermally populated excited states of $\mathrm{Dy}^{3+}$ [44]. Upon sample cooling, the $\chi_{\mathrm{m}} T$

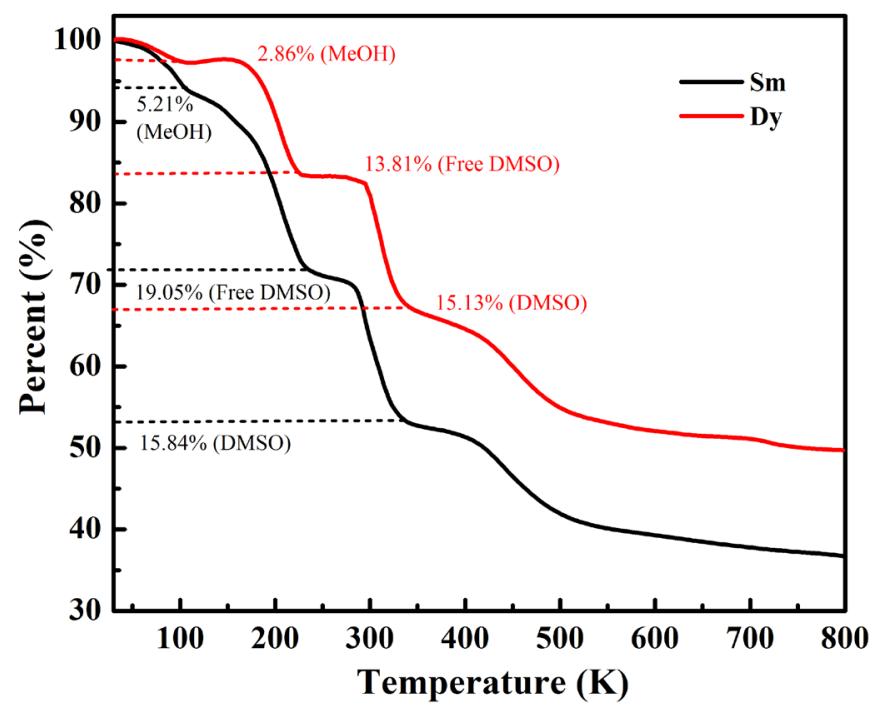

Figure 9. TGA curves of CPs 1 and 2. 


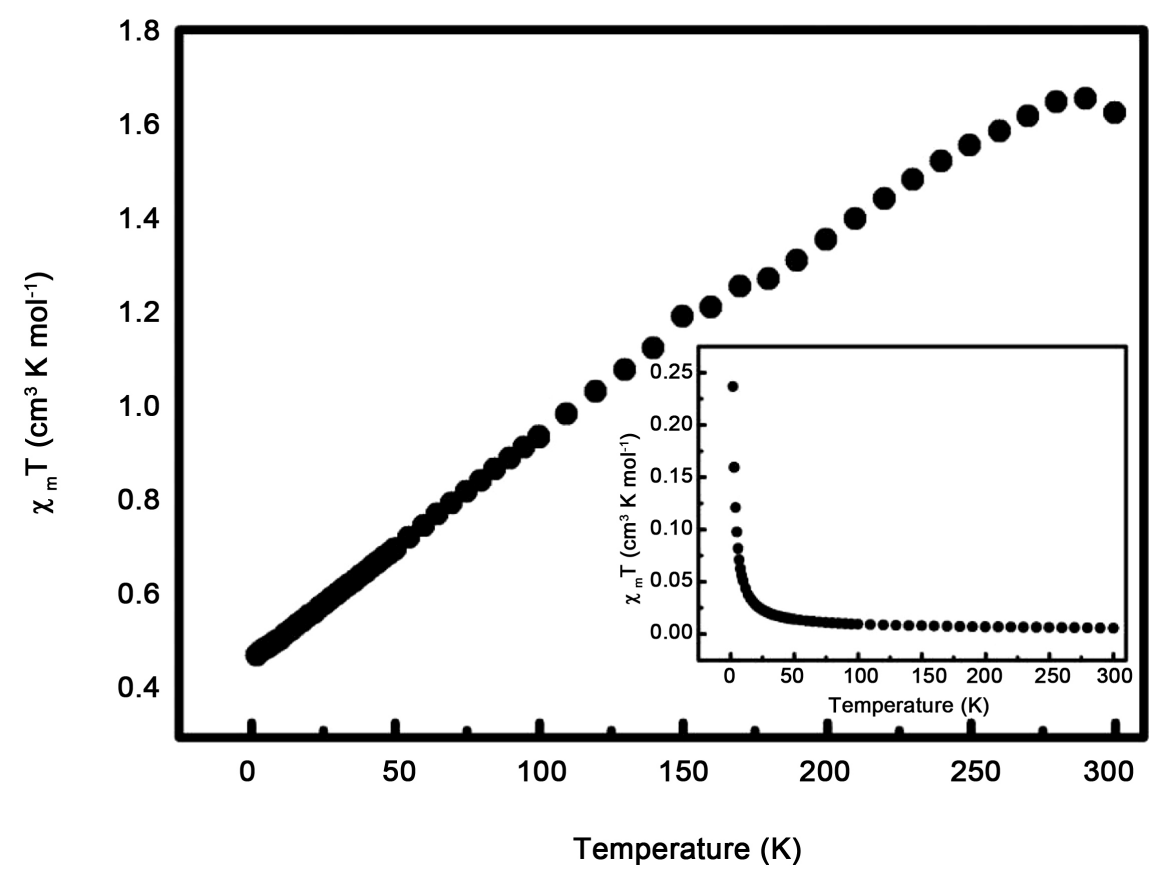

Figure 10. Plots of the temperature dependence of $\chi_{\mathrm{m}} T$ and $\chi_{\mathrm{m}}$ (insert) for CP-1.

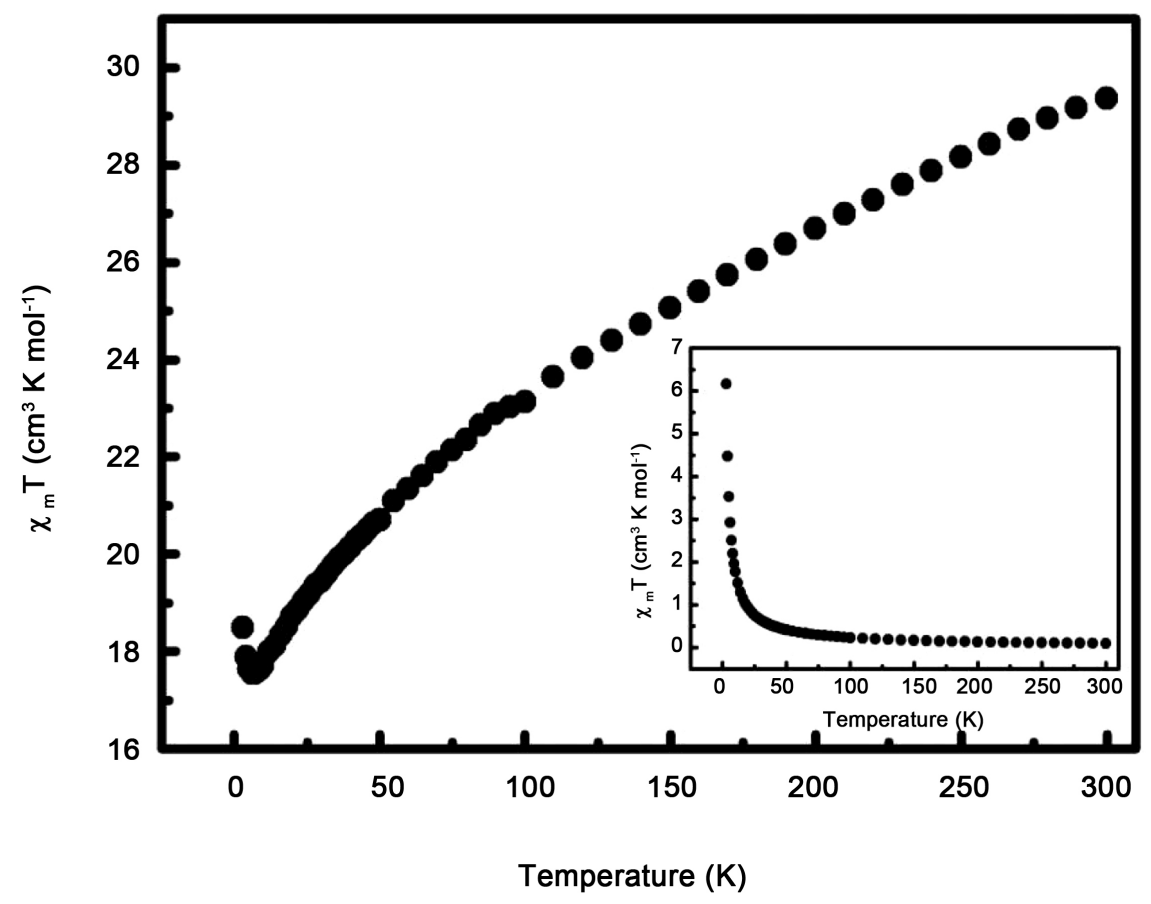

Figure 11. Plots of the temperature dependence of $\chi_{\mathrm{m}} T$ and $\chi_{\mathrm{m}}$ (insert) for CP-2.

value decreases continuously to a minimum value of $17.55 \mathrm{~cm}^{3} \mathrm{~K} \mathrm{~mol}^{-1}$ at $7 \mathrm{~K}$. After that, the $\chi_{\mathrm{m}} T$ value increases sharply to $18.49 \mathrm{~cm}^{3} \mathrm{~K} \mathrm{~mol}^{-1}$ at $1.8 \mathrm{~K}$. The transformation trend of $\chi_{\mathrm{m}} T$ curve below $7 \mathrm{~K}$ suggests the presence of weak intramolecular ferromagnetic correlation. And this magnetic difference is due to the different electron spin of the two center metals. The data in the range 100 - 
$300 \mathrm{~K}$ were fitted to the Curie-Weiss law, yielding $C=29.50 \mathrm{~cm}^{3} \mathrm{~K} \mathrm{~mol}^{-1}$ and $\theta=$ $-16.59 \mathrm{~K}$, which indicates the weak ferromagnetic interactions between the spincenters at $100-300 \mathrm{~K}$.

\section{Conclusion}

In summary, two interesting $3 \mathrm{D}$ heterobimetallic coordination polymers, $\left\{\left[\mathrm{Sm}_{2}(\mathrm{DMSO})_{4}\left(\mathrm{CH}_{3} \mathrm{OH}\right)_{2}\right]\left[\mathrm{L}^{\mathrm{Cu}}\right]_{3} \cdot 7 \mathrm{DMSO} \cdot 2 \mathrm{CH}_{3} \mathrm{OH}\right\}_{\mathrm{n}} 1$ and

$\left\{\left[\mathrm{Dy}_{2}(\mathrm{DMSO})_{3}-\left(\mathrm{CH}_{3} \mathrm{OH}\right)\right]\left[\mathrm{L}^{\mathrm{Cu} 3}(\mathrm{DMSO})\right] \cdot 4 \mathrm{DMSO} \cdot \mathrm{CH}_{3} \mathrm{OH}\right\}_{\mathrm{n}}$ 2, have been prepared from the reaction between metalloligand $\mathrm{L}^{\mathrm{Cu}}$ and lanthanoid ions $\left(\mathrm{Sm}^{3+}\right.$, $\left.\mathrm{Dy}^{3+}\right)$. Both CPs 1 and 2 possess the 3D consecutive framework structures, which are constructed from $\mathrm{L}^{\mathrm{Cu}}$ metalloligands connecting with six-connected $\left\{\mathrm{Sm}_{2}\right\}$ and $\left\{\mathrm{Dy}_{2}\right\}$ clusters, respectively. Thermal analysis indicates that the skeleton structures of CPs 1 and 2 begin to collapse after $350^{\circ} \mathrm{C}$. Magnetic measurements reveal that CPs 1 and 2 exhibit anti-ferromagnetic properties due to the contribution of $3 \mathrm{~d}-4 \mathrm{f}$ couplings. Further work to explore new metalloligand-based $3 \mathrm{~d}-4 \mathrm{f}$ heterobimetallic CPs with interesting magnetic and optical properties are currently in progress.

\section{Acknowledgements}

Financial support from the National Natural Science Foundation of China (Grants 50925207, 51172100, 51432006, and 51602130), the Ministry of Science and Technology of China for the International Science Linkages Program (Grants 2009DFA50620 and 2011DFG52970), the Ministry of Education of China for the Changjiang Innovation Research Team (Grant IRT13R24), the Ministry of Education and the State Administration of Foreign Experts Affairs for the 111 Project (Grant B13025), 100 Talents Program of CAS, Jiangsu Innovation Research Team and Natural Science Foundation of the Higher Education Institutions of Jiangsu Province (Grant16KJD430002) are gratefully acknowledged.

\section{References}

[1] Aboshyan-Sorgho, L., Cantuel, M., Petoud, S., Hauser, A. and Piguet, C. (2012) Optical Sensitization and Upconversion in Discrete Polynuclear Chromium-Lanthanide Complexes. Coordination Chemistry Reviews, 256, 1644. https://doi.org/10.1016/j.ccr.2011.12.013

[2] Salah, M.B., Vilminot, S., Andre, G., Bouree-Vigneron, F., Richard-Plouet, M., Mhiri, T. and Kurmoo, M.(2005) Nuclear and Magnetic Structures and Magnetic Properties of $\mathrm{Co}_{3}(\mathrm{OH})_{2}\left(\mathrm{SO}_{4}\right)_{2}\left(\mathrm{H}_{2} \mathrm{O}\right)_{2}$. Chemistry. Materials, 17, 2612. https://doi.org/10.1021/cm047790m

[3] Lee, K.J., Lee, J.H., Jeoung, S. and Moon, H.R. (2017) Transformation of Metal-Organic Frameworks/Coordination Polymers into Functional Nanostructured Materials: Experimental Approaches Based on Mechanistic Insights. Accounts of Chemical Research, 50, 2684. https://doi.org/10.1021/acs.accounts.7b00259

[4] Karmakar, A., Samanta, P., Desai, A.V. and Ghosh, S.K. (2017) Guest-Responsive Metal-Organic Frameworks as Scaffolds for Separation and Sensing Applications. Accounts of Chemical Research, 50, 2457. 
https://doi.org/10.1021/acs.accounts.7b00151

[5] Feng, X., Ma, L.F., Liu, L., Wang, L.Y., Song, H.L. and Xie, S.Y. (2013) A Series of Heterometallic Three-Dimensional Frameworks Constructed from Imidazole-Dicarboxylate: Structures, Luminescence, and Magnetic Properties. Crystal Growth \& Design, 13, 4469. https://doi.org/10.1021/cg4009587

[6] Khatua, S., Stoeckli-Evans, H., Harada, T., Kuroda, R. and Bhattacharjee, M. (2006) Helicity Induction through Hydrogen Bonding and Spontaneous Resolution of a Bimetallic Nickel Complex Coordinated to an Octahedral Metalloligand. Inorganic Chemistry, 45, 9619. https://doi.org/10.1021/ic061226r

[7] Mohapatra, C. and Chandrasekhar, V. (2014) Two-Dimensional Homometallic-to a Three Dimensional Heterometallic Coordination Polymer: A Metalloligand Approach. Crystal Growth \& Design, 14, 406. https://doi.org/10.1021/cg401698a

[8] Srivastava, S., Kumar, V. and Gupta, R. (2016) A Carboxylate-Rich Metalloligand and Its Heterometallic Coordination Polymers: Syntheses, Structures, Topologies, and Heterogeneous Catalysis. Crystal Growth \& Design, 16, 2874.

https://doi.org/10.1021/acs.cgd.6b00176

[9] Ma, Y.S., Li, H., Wang, J.J., Bao, S.S., Cao, R., Li, Y.Z. and Zheng, L.M. (2007) Three-Dimensional Lanthanide(III)-Copper(II) Compounds Based on anUnsymmetrical 2-Pyridylphosphonate Ligand: An Experimental and Theoretical Study. Chemistry: A European Journal, 13, 4759. https://doi.org/10.1002/chem.200601786

[10] Ma, Y.S., Song, Y. and Zheng, L.M. (2008) Nature of the LnIII-CoIImagnetic Interactions in Compounds $\left[\mathrm{Ln}_{2} \mathrm{Co}_{3}\left(\mathrm{C}_{5} \mathrm{H}_{4} \mathrm{NPO}_{3}\right)_{6}\right] \cdot 4 \mathrm{H}_{2} \mathrm{O}$ with Open-Framework Structures. Inorganic Chemistry Acta, 361, 1363. https://doi.org/10.1016/j.ica.2007.08.034

[11] MacLeod, J.M., Lipton-Duffin, J.A., Cui, D., Feyter, S. and Rosei, F. (2015) Substrate Effects in the Supramolecular Assembly of 1,3,5-Benzene Tricarboxylic Acid on Graphite and Graphene. Langmuir, 31, 7016-7024. https://doi.org/10.1021/la5048886

[12] Ryu, J.Y., Lee, J.M., Park, Y.J., Nghia, N.V., Lee, M.H. and Lee, J. (2013) A Ruthenium-Iron Bimetallic Supramolecular Cage with $D_{4}$ Symmetry from a Tetrapyridyl Iron(I) Metalloligand. Organometallics, 32, 7272-7274. https://doi.org/10.1021/om401145s

[13] Kobayashi, A., Suzuki, Y., Ohba, T., Ogawa, T., Matsumoto, T., Noro, S., Chang, H. and Kato, M. (2015) Systematic Syntheses and Metalloligand Doping of Flexible Porous Coordination Polymers Composed of a $\mathrm{Co}(\mathrm{III})$-Metalloligand. Inorganic Chemistry, 54, 2522-2535. https://doi.org/10.1021/ic5021302

[14] Watanabe, A., Kobayashi, A., Saitoh, E., Nagao, Y., Omagari, S., Nakanishi, T., Hasegawa, Y., Sameera, W.M., Yoshida, M. and Kato, M. (2017) Development of Ion-Conductive and Vapoluminescent Porous Coordination Polymers Composed of Ruthenium(II) Metalloligand. Inorganic Chemistry, 56, 3005-3013. https://doi.org/10.1021/acs.inorgchem.6b03123

[15] Zhang, S.Q., Han, L., Li, L.N., Cheng, J., Yuan, D.Q. and Luo, J.H. (2013) A Highly Symmetric Metal-Organic Framework Based on a Propeller-Like Ru-Organic Metalloligand for Photocatalysis and Explosives Detection. Crystal Growth \& Design, 13, 5466-5472. https://doi.org/10.1021/cg401438j

[16] Li, K., Zhang, L.Y., Yan, C., Wei, S.C., Pan, M., Zhang, L. and Su, C.Y. (2014) Stepwise Assembly of $\mathrm{Pd}_{6}\left(\mathrm{RuL}_{3}\right)_{8}$ Nanoscale Rhombododecahedral Metal-Organic Cages via Metalloligand Strategy for Guest Trapping and Protection. Journal of the American Chemical Society, 136, 4456-4459. https://doi.org/10.1021/ja410044r 
[17] Qian, J., Hu, J.C., Zhang, J.F., Yoshikawa, H., Awaga, K. and Zhang, C. (2013) Solvent-Induced Assembly of Octacyanometalates-Based Coordination Polymers with Unique afm1 Topology and Magnetic Properties. Crystal Growth \& Design, 13, 5211-5219. https://doi.org/10.1021/cg400909b

[18] Qian, J., Zhao, H.J., Wei, H.Y., Li, J.H., Zhang, J.F., Yoshikawa, H., Awagac, K. and Zhang, C. (2011) Two 3D Coordination Assemblies with Same Cluster Configuration Showing Different Magnetic Behaviors: A Ferromagnetic $\left\{\left[\mathrm{W}(\mathrm{CN})_{8} \mathrm{Co}_{2}(\mathrm{DMF})_{8}\right]\left[\mathrm{NO}_{3}\right]\right\}_{n}$ and a Paramagnetic $\left\{\mathrm{W}(\mathrm{CN})_{8} \mathrm{Cu}_{2}(\text { py })_{8}\right\}_{n}$. CrystEngComm, 13, 517-523. https://doi.org/10.1039/C0CE00227E

[19] Li, J.H., Jia, D., Meng, S.C., Zhang, J.F., Cifuentes, M.P., Humphrey, M.G. and Zhang, C. (2015) Tetrazine Chromophore-Based Metal-Organic Frameworks with Unusual Configurations: Synthetic, Structural, Theoretical, Fluorescent, and Nonlinear Optical Studies. Chemistry-A European Journal, 21, 7914-7926. https://doi.org/10.1002/chem.201404803

[20] Zhang, J.F., Jia, D., Humphrey, M.G., Meng, S.C., Zaworotko, M.J., Cifuentes, M.P. and Zhang, C. (2016) Ammonium-Crown Ether Supramolecular Cation-Templated Assembly of an Unprecedented Heterobicluster-Metal Coordination Polymer with Enhanced NLO Properties. Chemical Communications, 52, 3797-3800.

[21] Noro, S., Miyasaka, H., Kitagawa, S., Wada, T., Okubo, T., Yamashita, M. and Mitani, T. (2005) Framework Control by a Metalloligand Having Multicoordination Ability: New Synthetic Approach for Crystal Structures and Magnetic Properties. Inorganic Chemistry, 44, 133-146. https://doi.org/10.1021/ic049550e

[22] Banerjee, D., Zhang, Z.J., Plonka, A.M., Li, J. and Parise, J.B. (2012) A Calcium Coordination Framework Having Permanent Porosity and High $\mathrm{CO}_{2} / \mathrm{N}_{2}$ Selectivity. Crystal Growth \& Design, 12, 2162-2165. https://doi.org/10.1021/cg300274n

[23] Mundwiler, S., Kundig, M., Ortner, K. and Alberto, R. (2004) A New [2 + 1] Mixed Ligand Concept Based on $\left[{ }^{99(\mathrm{~m})} \mathrm{Tc}\left(\mathrm{OH}_{2}\right)_{3}(\mathrm{CO})_{3}\right]^{+}$: A Basic Study. Dalton Transactions, 1320-1328. https://doi.org/10.1039/B400220B

[24] Noro, S., Kitagawa, S., Yamashita, M. and Wada, T. (2002) New Microporous Coordination Polymer Affording Guest-Coordination Sites at Channel Walls. Chemical Communications, 222-223. https://doi.org/10.1039/b108695b

[25] Liang, Y.C., Cao, R., Hong, M.C., Sun, D.F., Zhao, Y.J., Weng, J.B. and Wang, R.H. (2002) Syntheses and Characterizations of Two Novel Ln(III)-Cu(II) Coordination Polymers Constructed by Pyridine-2,4-Dicarboxylate Ligand. Inorganic Chemistry Communications, 5, 366-368. https://doi.org/10.1016/S1387-7003(02)00385-4

[26] Chen, Y.M., Gao, Q., Chen, W.Q., Gao, D.D., Li, Y.H., Liu, W. and Li, W. (2015) Heterometallic $\mathrm{Sr}(\mathrm{II})-\mathrm{M}(\mathrm{II})(\mathrm{M}=\mathrm{Co}, \mathrm{Ni}, \mathrm{Zn}$ and $\mathrm{Cu}$ ) Coordination Polymers: Synthesis, Temperature-Dependent Structural Transformation, and Luminescent and Magnetic Properties. Chemistry-An Asian Journal, 10, 411.

[27] Zhou, Q., Qian, J. and Zhang, C. (2013) Three Interesting Coordination Compounds Based on Metalloligandand Alkaline-Earth Ions: Syntheses, Structures, Thermal Behaviors and Magnetic Property. Journal of Molecular Structure, 1049, 326.

[28] Huang, Y.G., Wu, M.Y., Wei, W., Gao, Q., Yuan, D.Q., Jiang, F.L. and Hong, M.C. (2008) Unprecedented Ferromagnetic Interaction in an Erbium(III)-Copper(II) Coordination Polymer. Journal of Molecular Structure, 885, 23-27. https://doi.org/10.1016/j.molstruc.2007.10.002

[29] Huang, Y.G., Wu, M.Y., Lian, F.Y., Jiang, F.L. and Hong, M.C. (2008) Twofold Interpenetration Corrugated Brick Wall Frameworks of 3d-4f Heterometallic Coordination Polymers. Inorganic Chemistry Communications, 11, 840-842. 
[30] John, C.M., Pieter, C.D., Malissa, M.P., Mary, M.F., Jaina, L.L. and Jamie, L.M. (2000) Design of Layered Crystalline Materials Using Coordination Chemistry and Hydrogen Bonds. Journal of the American Chemical Society, 122, 11692.

https://doi.org/10.1021/ja002102v

[31] Lush, S.F. and Shen, F.M. (2010) Poly[hexaaquahexakis(l-pyridine-2,4-dicarboxylato)tricopper(II)-dieuropium(III)]. Acta Crystallographica, E66, m1516-m1517.

[32] Tang, Y.Z., Wen, H.R., Cao, Z., Wang, X.W., Huang, S. and Yu, C.L. (2010) A Novel Three Dimensional 3d-4f Heterometallic Coordination Framework with 2,2'-Bipyridine-3-Carboxylate and Oxalate Ligands. Inorganic Chemistry Communications, 13, 924-928.

[33] Tang, Y.Z., Yang, Y.M., Wang, X-W., Zhang, Q. and Wen, H.R. (2011) Synthesis, Structure and XPS of a Novel Two-Dimensional $\mathrm{Cu}^{\mathrm{II}}-\mathrm{Eu}^{\mathrm{III}}$ Heterometallic-Organic Framework. Inorganic Chemistry Communications, 14, 613-617. https://doi.org/10.1016/j.inoche.2011.01.015

[34] Lipstman, S. and Goldberg, I. (2010) Porphyrin Framework Solids. Hybrid Supramolecular Assembly Modes of Tetrapyridylporphyrin and Aqua Nitrates of Lanthanoid Ions. Crystal Growth \& Design, 10, 1823-1832.

https://doi.org/10.1021/cg901505m

[35] Tăbăcaru, A., Pettinari, C., Timokhin, I., Marchetti, F., Carrasco-Marín, F., Maldonado-Hódar, F.J., Galli, S. and Masciocchi, N. (2013) Enlarging an Isoreticular Family: 3,3',5,5'-Tetramethyl-4,4'-Bipyrazolato-Based Porous Coordination Polymers. Crystal Growth \& Design, 13, 3087-3097. https://doi.org/10.1021/cg400495w

[36] Tang, Y.Y., Cui, M.Y., Guo, W.B., Zhang, S.Y., et al. (2015) Syntheses, Structure, and Magnetic Properties of New 3d-4f Heterometallic Hydroxysulfates $\operatorname{Ln}_{2} \mathrm{Cu}\left(\mathrm{SO}_{4}\right)_{2}(\mathrm{OH})_{4}$ $(\mathrm{Ln}=\mathrm{Sm}, \mathrm{Eu}, \mathrm{Tb}$, or Dy) with a Two-Dimensional Triangle Network. Crystal Growth \& Design, 15, 2742-2747. https://doi.org/10.1021/acs.cgd.5b00057

[37] He, X.X., Cheng, W.W., Lin, Q.F., Dong, Y.Y. and Xu, Y. (2017) Syntheses, Structures, Luminescence, and Magnetic Properties of a Series of Novel Coordination Polymers Constructed by Nanosized $\left[\mathrm{Ln}_{8} \mathrm{Fe}_{4}\right]$ Rings. Crystal Growth \& Design, 17, 347-254. https://doi.org/10.1021/acs.cgd.6b01576

[38] Ralph, A.Z., Christopher, S.W., Hunter, T.C., Kenneth, S.H., Varun, C. and Robert, A.R. (2011) Effect of Inclining Strain on the Crystal Lattice along an Extended Series of Lantha-nide Hydroxysulfates $\mathrm{Ln}(\mathrm{OH}) \mathrm{SO}_{4}(\mathrm{Ln}=\mathrm{Pr}-\mathrm{Yb}$, Except $\mathrm{Pm})$. Inorganic Chemistry, 50, 836. https://doi.org/10.1021/ic101350f

[39] Su, Y.H., Bao, S.S. and Zheng, L.M. (2014) Heterometallic 3d-4f Coordination Polymers Based on 1,4,7-Triazacyclononane-1,4,7-triyl-tris(methylenephosphonate). Inorganic Chemistry, 53, 6042-6047. https://doi.org/10.1021/ic500356b

[40] (1997) SMART and SAINT Area Detector Software Package and SAX Area Detector Integration Program Bruker Analytical X-Ray. Madison, WI, USA.

[41] Sheldrick, G.M. (1996) SADABS, Program for Area Detector Adsorption Correction. Institute for Inorganic Chemistry, University of Göttingen, Germany.

[42] Sheldrick, G.M. (1997) SHELXL-97, Program for Refinement of Crystal Structures. University of Göttingen, Germany.

[43] Spek, A.L. (2003) Single-Crystal Structure Validation with the Program PLATON. Journal of Applied Crystallography, 36, 7-13. https://doi.org/10.1107/S0021889802022112

[44] Zhang, F.M., Yan, P.F., Zou, X.Y., Zhang, J.W., Hou, G.F. and Li, G.M. (2014) Novel 3D Alkali-Lanthanide Heterometal-Organic Frameworks with Pyrazine-2,3,5,6-Tetracarboxylic Acid: Synthesis, Structure, and Magnetism. Crystal Growth \& Design, 14, 2014-2021. https://doi.org/10.1021/cg5001254 